\title{
CORRELATION BETWEEN THE SCHANZ SCREW INSERTION ANGLE AND THE LOSS OF KYPHOSIS CORRECTION IN THORACOLUMBAR FRACTURES
}

\author{
CORRELAĈ̃O ENTRE O ÂNGULO DE INSERÇÃO DO PINO DE SCHANZ E A PERDA DE \\ CORREÇÃO DA CIFOSE EM FRATURAS TORACCOLOMBARES \\ CORRELACIÓN ENTRE EL ÁNGULO DE INSERCIÓN DEL TORNILLO DE SCHANZ Y LA \\ PÉRDIDA DE CORRECCIÓN DE LA CIFOSIS EN FRACTURAS TORACOLUMBARES
}

\author{
Fabio Antonio Vieira, ${ }^{1}$ André Sousa Garcia, ${ }^{2}$ Fernando Tadashi Salvioni Ueta, ${ }^{1}$ David Del Curto, ${ }^{1}$ Renato Hiroshi Salvioni Ueta, ${ }^{1}$ Eduardo Barros Puertas ${ }^{2}$ \\ 1. Universidade Federal de São Paulo, Department of Orthopedics and Traumatology, Spine Group, São Paulo, SP, Brazil. \\ 2. Universidade Federal de São Paulo, Department of Orthopedics and Traumatology, São Paulo, SP, Brazil.
}

\begin{abstract}
Objective: To compare the Schanz screw insertion angle and the loss of the regional kyphosis correction in thoracolumbar burst fractures following posterior short instrumentation surgery. Methods: Patients with a thoracolumbar burst fracture between levels T11- $L 2$ were divided into two groups (parallel and divergent) according to the angle formed between the Schanz screw and the vertebral plateau. Regional kyphosis was evaluated in preoperative, immediate postoperative and last follow-up radiographs. Results: Of the 58 patients evaluated, 31 had a parallel assembly and 27 had a divergent assembly. When we analyzed the angle of kyphosis, no statistical difference was observed between the pre- and postoperative radiographs. However, a statistical difference in the last follow-up radiographs and in the final loss of the kyphosis correction was confirmed. Conclusion: The insertion of Schanz screws with a divergent assembly presents better radiographic results with less loss of kyphosis correction angle when compared with the parallel assembly technique. Level of Evidence III; Retrospective cohort study.
\end{abstract}

Keywords: Thoracolumbar Fractures; Short-Segment Fixation; Posterior Fixation; Kyphosis.

\section{RESUMO}

Objetivo: Comparar o ângulo de inserção do pino de Schanz e os resultados da perda de correção da cifose regional nas fraturas toracolombares do tipo explosão após tratamento cirúrgico com instrumentação curta por via posterior. Métodos: Os pacientes com fratura toracolombar do tipo explosão entre os níveis de T11-L2 foram divididos em dois grupos (paralelo e divergente) de acordo com o ângulo formado entre o pino de Schanz e o platô vertebral. Foi avaliada a cifose regional nas radiografias pré-operatória, pós-operatória imediata e do último acompanhamento. Resultados: Dos 58 pacientes avaliados, 31 apresentaram uma montagem paralela e 27 uma montagem divergente. Ao analisarmos o ângulo da cifose, não se observou diferença estatística nas radiografias pré- e pós-operatória imediata. Porém, verificou-se uma diferença estatística nas radiografias do último acompanhamento e na perda final de correção da cifose. Conclusões: A inserção do pino de Schanz com uma montagem divergente apresenta melhores resultados radiográficos com menor perda do ângulo de correção da cifose quando comparada com a técnica de montagem paralela. Nível de Evidência III; Estudo de coorte retrospectivo.

Descritores: Fratura Toracolombar; FixaÇão Curta; Fixação Posterior; Cifose.

\section{RESUMEN}

Objetivo: Comparar el ángulo de inserción del tornillo de Schanz y los resultados de la pérdida de corrección de la cifosis regional en las fracturas toracolumbares del tipo explosión después del tratamiento quirúrgico con instrumentación corta por vía posterior. Métodos: Los pacientes con fractura toracolumbar del tipo explosión entre los niveles de T11-L2 fueron divididos en dos grupos (paralelo y divergente) de acuerdo con el ángulo formado entre el tornillo de Schanz y la meseta vertebral. Fue evaluada la cifosis regional en las radiografías preoperatoria, posoperatoria inmediata y del último acompañamiento. Resultados: De los 58 pacientes evaluados, 31 presentaron un montaje paralelo y 27 un montaje divergente. Al analizar el ángulo de la cifosis, no se observó diferencia estadística en las radiografías pre y postoperatoria inmediata. Sin embargo, se verificó una diferencia estadística en las radiografías del último acompañamiento y en la pérdida final de corrección de la cifosis. Conclusiones: La inserción del tornillo de Schanz con un montaje divergente presenta mejores resultados radiográficos con menor pérdida del ángulo de corrección de la cifosis cuando comparada con la técnica de montaje paralelo. Nivel de Evidencia III; Estudio de cohorte retrospectivo.

Descriptores: Fracturas Toracolumbares; Fijación Corta; Fijación Posterior; Cifosis. 


\section{INTRODUCTION}

A high incidence of spinal fractures occurs in the thoracic or lumbar region. ${ }^{1}$ Most of these injuries are between segments T10-L2, which comprise the thoracolumbar junction. ${ }^{1}$ The objective of surgical treatment of unstable thoracolumbar fractures is to restore the alignment and stability of the spine and to achieve decompression of neural elements if necessary, allowing the early mobilization of the patient. ${ }^{2,3}$ The ideal treatment for these fractures is still a matter of debate, motivating studies over the last few decades that have enabled the development of new concepts and more efficient procedures for the early rehabilitation of patients.

Posterior instrumentation is often used in surgeries for unstable thoracolumbar fractures. ${ }^{4-8}$ Transpedicular short segment fixation became popular after the introduction of pedicle screws by Roy-Camille et al. and the internal fixator by Dick et al. ${ }^{9,10}$ The internal fixator stands out for being an injury stabilization and reduction assembly system made up of screws, rods, and connectors that enables the correction of deformity in the different planes, acting as a tension band, a buttress, or a neutralization system. ${ }^{11,12}$ With the use of the internal fixator, it became possible to achieve better correction of kyphotic deformity, greater initial stability, early painless mobilization, and indirect decompression of the vertebral canal, with decreases in interoperative bleeding and surgical time. ${ }^{13-15}$ However, the correction obtained in the sagittal plane may be lost in long-term follow-up and in some cases reconstruction of the anterior spine is required to prevent collapse due to kyphosis. ${ }^{16-19}$

The Schanz screw insertion angle can influence the final stability of the system. The biomechanical study proposed by Ouellet et al. ${ }^{20}$ analyzed the difference between the resistance of divergent and parallel assemblies and observed that the former offered greater stability. However, this study on cadavers did not evaluate the effect of prolonged mechanical stress. To date, no study has comparatively evaluated the results of these two assemblies in vivo.

The objective of this study is to evaluate the correlation between the Schanz screw sagittal plane insertion angle in short instrumentations and the loss of kyphotic correction in the respective long-term follow-ups.

\section{METHODS}

Patients with thoracolumbar burst fractures of a single segment between levels T11-L2 without neurological deficit who underwent short posterior instrumentation without arthrodesis using the $\mathrm{AO}$ internal fixator at the Hospital São Paulo of the Universidade Federal de São Paulo, during the period from January 2008 to July 2015 were evaluated. The study was approved by the Institutional Review Board as protocol number CAAE: 73689716.5.0000.550 and all the patients agreed with and signed the informed consent form (ICF).

The fractures were classified according to the AO Spine ${ }^{21}$ criteria for traumatic thoracolumbar spinal fractures. Unstable burst fractures (A3 and A4) with a loss of vertebral body height greater than $50 \%$ or with regional kyphosis of $25^{\circ}$ were included in the study. All patients underwent posterior stabilization within the first three days following the injury with transpedicular Schanz screws inserted in the vertebrae above and below the level of the fractured bone, without arthrodesis. The reduction of the kyphosis angle was achieved using the technique recommended for use of the $\mathrm{AO}$ internal fixator ${ }^{22}$ (Universal Spine System, DePuy Synthes, West Chester, PA). The implants were not routinely removed and no patient required an additional approach.

Radiographs of the thoracolumbar spine in the preoperative period, immediately following surgery, and at the last follow-up were used. The configuration of the internal fixator system assembly was categorized according to the angle formed between the Schanz pedicle screws and the terminal plate of the vertebra. (Figure 1) The patients were divided into two groups: Group 1, parallel assembly in which the sum of angles I and $S$ is less than $10^{\circ}$ and Group 2, divergent assembly in which the sum of these angles is greater than $10^{\circ}$. Regional kyphosis was calculated by the Cobb method, one vertebra above and one vertebra below the fracture. (Figure 2)

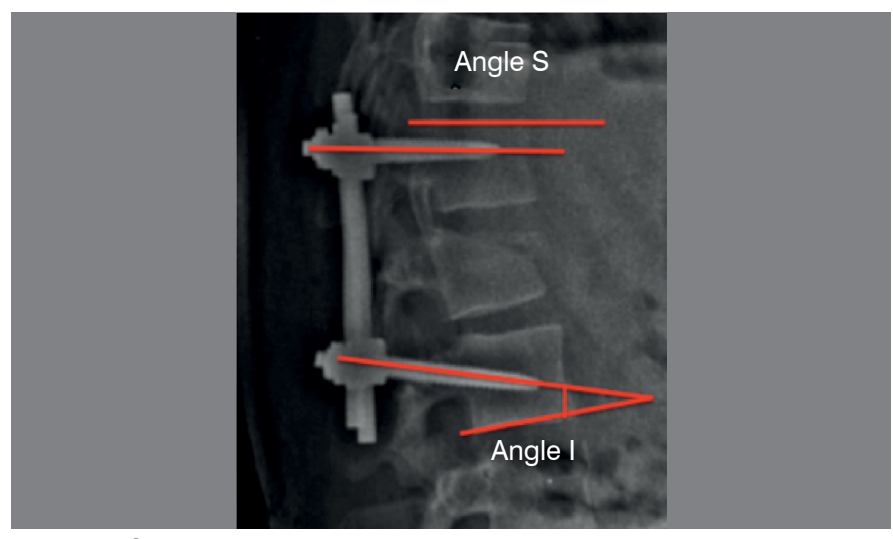

Figure 1. Schanz screw insertion angle.

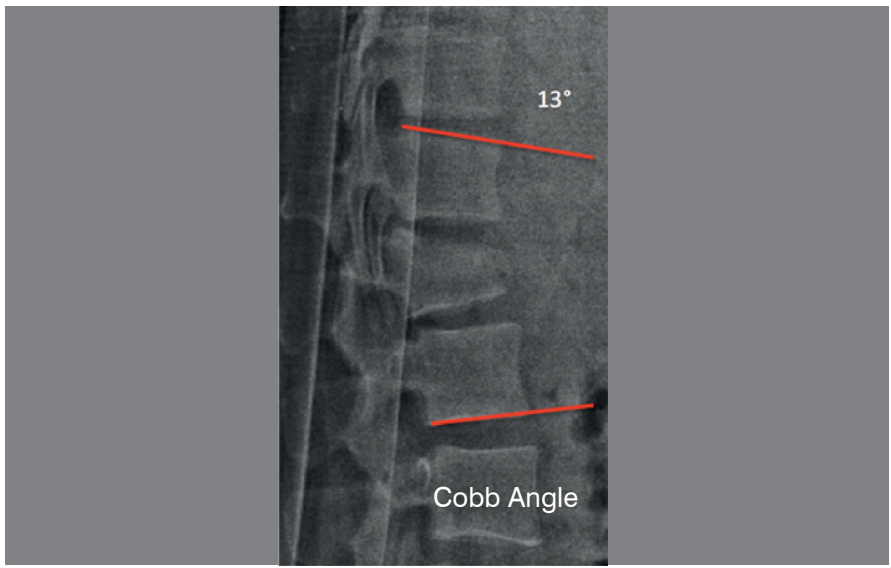

Figure 2. Regional kyphosis calculated using the Cobb method

The loss of correction of the kyphosis angle at the end of follow-up in relation to the immediate postoperative period, as well as its correlation with the configuration of the system assembled was analyzed using the ANOVA test. A probability value less than 0.05 was considered statistically significant.

\section{RESULTS}

Of the 58 patients treated with the Schanz screw technique, 40 were men and 18 were women, with a mean age of 41.6 years (15-61 years). The mean follow-up time was 62 months (16-108 months). Six patients had a fracture in T11, nine in T12, 23 in L1, and 20 in L2. Groups 1 and 2 were similar in terms of age, sex, and follow-up time (Table 1). Thirty-one patients presented a parallel assembly $\left(<10^{\circ}\right)$ and 27 patients a divergent assembly $\left(>10^{\circ}\right)$.

Table 2 shows the distribution of the preoperative, immediate postoperative, and most recent follow-up regional kyphosis angles, as well as the loss of correction of kyphosis. Figure 3 shows the comparison of the kyphosis angle values between the groups.

There was an improvement between the preoperative and immediate postoperative angles of kyphosis of $16.54^{\circ}$ in Group 1 and $15.89^{\circ}$ in Group 2. There was no statistical difference when this value was compared between the groups $(p=0.47)$. The difference between the mean angles in the immediate postoperative period and at the last follow-up (loss of kyphosis correction) was $12.26^{\circ}$ $\left(4-18^{\circ}\right)$ in Group 1 and 8.59 $\left(2-18^{\circ}\right)$ in Group 2, indicating a statistical difference $(p=0.001)$.

\section{DISCUSSION}

The thoracolumbar junction constitutes a transitional zone between the rigid thoracic spine and the mobile lumbar spine. Fractures in this region can be unstable, evolving with significant kyphotic deformity. ${ }^{23,24}$ Conservative treatment is recommended for stable 
Table 1. Demographic distribution.

\begin{tabular}{|c|c|c|c|c|c|c|c|}
\hline & & & & Mean & Min & Max & P-value \\
\hline \multirow{2}{*}{\multicolumn{2}{|c|}{ Age }} & \multicolumn{2}{|c|}{ Group 1} & 39.81 & 19 & 59 & \multirow{2}{*}{0.762} \\
\hline & & \multicolumn{2}{|c|}{ Group 2} & 40.85 & 15 & 61 & \\
\hline \multirow{2}{*}{\multicolumn{2}{|c|}{ Follow-up }} & Group & & 59.65 & 15 & 108 & \multirow{2}{*}{0.811} \\
\hline & & \multicolumn{2}{|c|}{ Group 2} & 57.70 & 16 & 106 & \\
\hline \multirow{2}{*}{ Sex } & \multicolumn{2}{|c|}{ Group 1} & \multicolumn{2}{|c|}{ Group 2} & \multicolumn{2}{|c|}{ P-value } & \\
\hline & $\mathbf{N}$ & $\%$ & $\mathbf{N}$ & $\%$ & & & \\
\hline Female & 8 & $25.8 \%$ & 10 & $37.0 \%$ & \multirow{2}{*}{\multicolumn{2}{|c|}{0.356}} & \\
\hline Male & 23 & $74.2 \%$ & 17 & $63.0 \%$ & & & \\
\hline
\end{tabular}

Table 2. Comparison of the kyphosis angle values.

\begin{tabular}{c|c|c|c|c|c|c|c}
\hline \multicolumn{2}{c|}{} & Mean & $\begin{array}{c}\text { Standard } \\
\text { Deviation }\end{array}$ & Min & Max & CI & P-value \\
\hline \multirow{2}{*}{$\begin{array}{c}\text { Preoperative } \\
\text { Angle }\end{array}$} & Group 1 & 19.06 & 5.51 & 8 & 29 & 1.94 & \multirow{2}{*}{0.609} \\
\cline { 2 - 8 } & Group 2 & 18.37 & 4.64 & 10 & 28 & 1.75 & \\
\hline \multirow{2}{*}{$\begin{array}{c}\text { Postoperative } \\
\text { Angle }\end{array}$} & Group 1 & 2.23 & 3.52 & -3 & 10 & 1.24 & \multirow{2}{*}{0.776} \\
\cline { 2 - 8 } & Group 2 & 2.48 & 3.24 & -4 & 8 & 1.22 & \\
\hline \multirow{2}{*}{ Final Angle } & Group 1 & 14.48 & 4.39 & 6 & 23 & 1.54 & \multirow{2}{*}{0.002} \\
\cline { 2 - 8 } & Group 2 & 11.07 & 3.50 & 5 & 18 & 1.32 & \\
\hline \multirow{2}{*}{ Correction Loss } & Group 1 & 12.26 & 3.92 & 4 & 18 & 1.38 & \multirow{2}{*}{0.001} \\
\cline { 2 - 8 } & Group 2 & 8.59 & 3.73 & 2 & 18 & 1.41 & \\
\hline
\end{tabular}

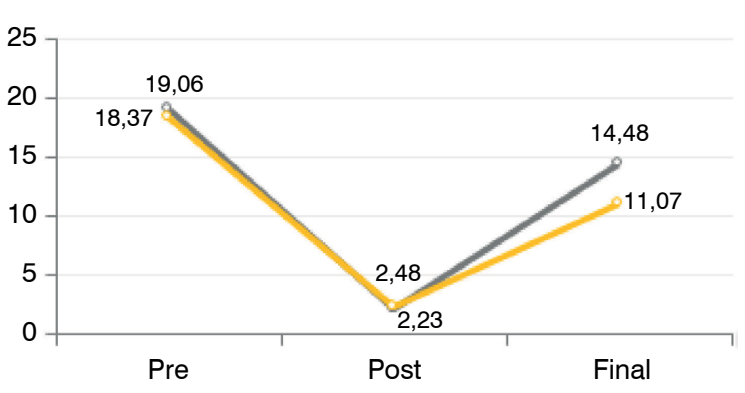

$=$ Group $1 \quad$ Group 2

Figure 3. Evolution of the regional kyphosis angle.

fractures without neurological changes, ${ }^{25}$ but it does not always have an adequate and predictable outcome. ${ }^{26,27}$ Surgical treatment of these fractures can be performed by posterior, anterior, or combined approach. Posterior approach short segment instrumentation was introduced by Roy-Camille ${ }^{28}$ in 1998 and has the advantage of less bleeding, a smaller area of muscle dissection, and it incorporates fewer levels of arthrodesis. ${ }^{29-31}$

Studies that evaluate anterior instrumentation ${ }^{32,33}$ and compare it with the posterior approach cite late correction loss as the major disadvantage of the posterior approach. In the case of a single approach, there is a preference for the posterior approach for its technical advantages, however, when the anatomy of the injury clearly demonstrates failures of the anterior and middle spine, the anterior approach should be performed to complement the posterior procedure. Yu et al., ${ }^{34}$ in their retrospective study of 20 patients submitted to short arthrodeses, reported a high failure rate (breakage of the implant and/or pseudoarthrosis), also stating the need for complementation by anterior approach with grafting and instrumentation to ensure a more satisfactory outcome. On the other hand, Verlaan ${ }^{35}$ conducted a systematic review of the last thirty years, evaluating all the methods: anterior approach, posterior approach with short and long arthrodeses, and combined approaches and did not find significant differences among the proposed techniques regarding maintenance of the correction.

Short instrumentation is considered a viable option for the treatment of thoracolumbar fractures. ${ }^{36,37}$ The comparison between long and short fixation is a highly debated topic and each type of instrumentation is associated with specific advantages and disadvantages. Tezerem et al. ${ }^{38}$ prospectively evaluated the clinical and radiographic results of two groups of patients treated with short or long instrumentation for thoracolumbar fractures. Measuring the local kyphosis, sagittal index, and vertebral height showed that the long instrumentation group had better radiological results at the end of follow-up. However, there was no statistical difference between the clinical results of the two groups.

Much is said about the need for arthrodesis in patients undergoing posterior short instrumentation. In their prospective, randomized study, Wang et al. ${ }^{39}$ divided the patients treated with posterior short instrumentation into two groups: with and without arthrodesis. They observed that arthrodesis is not itself necessary; both groups evolved with a loss of correction during follow-up with no statistical difference between them. They saw the fact that complications (pain, fracture of the iliac crest, paresthesia, and infection) could be avoided by the removal of the graft as an advantage of the technique with arthrodesis, in addition to its shorter surgical time.

The biomechanical study conducted by Ouellet et al. ${ }^{20}$ analyzed the difference between parallel and divergent Schanz screw insertion assemblies. In all the models the divergent assembly was observed to be more rigid and stable than the parallel. This greater rigidity of the divergent assembly is due to the greater strength that exists in the interface between the point of the screw and the subchondral bone, as opposed to the parallel assembly, in which the interface is with spongy bone. Another factor that contributed to its greater resistance is that the divergent assembly decomposes the compressive force vector, reducing the load on the anterior spine.

This study was composed of patients with thoracolumbar burst fractures (T11-L2) classified as A3 or A4 by the AOSpine classification. ${ }^{21}$ The mean regional preoperative kyphosis of the 58 patients evaluated in the study was $18.74^{\circ}$, correcting for a mean value of $2.37^{\circ}$, which presented a mean loss of correction of $10.55^{\circ}$ during follow-up. These values are like those of previous studies that reported a loss of kyphosis correction during follow-up in patients treated with short instrumentation.

When we divided the patients into two groups according to the Schantz screw angulation, one being a parallel assembly and the other divergent, we observed a statistically significant difference between the two groups in loss of correction at the final follow-up: $12.26^{\circ}$ in Group 1 and $8.59^{\circ}$ in Group 2, $(p<0.05)$. These data corroborate the biodynamic findings of Ouellet et al., ${ }^{20}$ who observed greater resistance of the Schanz screws to compression forces in the divergent system assembly.

One of the limitations of this study was that it did not evaluated the quality of life indices in the pre- and postoperative periods. In this respect, the work of Sanderson and Fraser ${ }^{40}$ showed that, despite the loss of kyphosis correction, there was no correlation with patients' physical function, pain, or quality of life. A prospective, randomized study comparing these two forms on Schanz screw insertion assemblies may be necessary to accurately determine the best technique for preventing the loss of kyphosis correction in patients with thoracolumbar fractures treated with short fixation.

\section{CONCLUSION}

Based on the results obtained in this study, we conclude that Schantz screw insertion with a divergent assembly presents better radiographic results, with less loss of the kyphotic correction angle in long-term follow-up, when compared to the parallel assembly technique in patients with thoracolumbar fracture treated with short instrumentation.

$\overline{\text { All authors declare no potential conflict of interest related to }}$ this article. 
CONTRIBUTION OF THE AUTHORS: Each author made significant individual contributions to this manuscript. FAV and ASG were the main contributors to the writing of the manuscript. FAV, FTSU, DDC, RHSU and EBP performed the surgeries and collected the data. FAV and ASG evaluated the statistical analysis data. FAV, ASG and FTSU conducted the bibliographical research. DDC, RHSU and EBP reviewed the manuscript and contributed to the intellectual concept of the study.

\section{REFERENCES}

1. Defino HLA. Particularidades do trauma na coluna toracolombar. In: Pardini Júnior AG, Souza JMG, Barros Filho TEP, editores. Clínica ortopédica. Rio de Janeiro: MEDSI; 2000. 863-84.

2. Alvine GF, Swain JM, Asher MA, Burton DC. Treatment of thoracolumbar burst fractures with variable screw placement or Isola instrumentation and arthrodesis: case series and literature review. J Spinal Disord Tech. 2004;17(4):251-64.

3. Briem D, Lehmann W, Ruecker AH, Windolf J, Rueger JM, Linhart W. Factors influencing the quality of life after burst fractures of the thoracolumbar transition. Arch Orthop Trauma Surg. 2004;124(7):461-8.

4. Katonis PG, Kontakis GM, Loupasis GA, Aligizakis AC, Christoforakis JI, Velivassakis EG. Treatment of unstable thoracolumbar and lumbar spine injuries using Cotrel-Dubousset instrumentation. Spine (Phila Pa 1976). 1999;24(22):2352-7.

5. Li KC, Hsieh CH, Lee CY, Chen TH. Transpedicle body augmenter: a further step in treating burst fractures. Clin Orthop Relat Res. 2005:(436):119-25.

6. Müller U, Berlemann U, Sledge J, Schwarzenbach O. Treatment of thoracolumbar burst fractures without neurologic deficit by indirect reduction and posterior instrumentation: bisegmental stabilization with monosegmental fusion. Eur Spine J. 1999;8(4):284-9.

7. Sasso RC, Best NM, Reilly TM, McGuirre RA Jr. Anterior-only stabilization of three column thoracolumbar injuries. J Spinal Disord Tech. 2005;18 Suppl:S7-14

8. Varlaan JJ, Diekerhof $\mathrm{CH}$, Buskens E, van der Tweel I, Verbout AJ, Dhert WJ, et al. Surgical treatment of traumatic fractures of the thoracic and lumbar spine: a systematic review of the literature on techniques, complications, and outcome. Spine (Phila Pa 1976). 2004;29(7):803-14.

9. Roy-Camille R, Roy-Camille M, Demeulenaer C. Osteosynthese du Rachis dorsal, lombaire et lombosacre par plaques metalliques vissees dans les pedicles vertebraux et les apophyses articularies. Presse Med. 1970;78:1447-8.

10. Dick W, Kluger $P$, Magerl F. Woersdörfer $O$, Zäch G. A new device for internal fixation of thoracolumbar and lumbar spine fractures: the fixateur interne. Paraplegia. 1985;23(4):225-32.

11. Aebi M, Etter $C$, Kehl T, Thalgott J. The internal skeletal fixation system. A new treatment of thoracolumbar fractures and other spinal disorders. Clin Orthop Relat Res. 1988:227:30-43.

12. Magerl FP. Stabilization of the lower thoracic and lumbar spine with external skeletal fixation. Clin Orthop Relat Res. 1984;(189):125-41.

13. Louis CA, Gauthier VY, Louis RP. Posterior approach with Louis plates for fractures of the thoracolumbar and lumbar spine with and without neurologic deficits. Spine (Phila Pa 1976). 1998;23(18):2030-9; discussion 2040

14. Shen WJ, Liu TJ, Shen YS. Nonoperative treatment versus posterior fixation for thoracolumbar junction burst fractures without neurologic deficit. Spine (Phila Pa 1976). 2001;26(9):1038-45

15. Sjostrom L, Karlstrom G, Pech P, Rauschning W. Indirect spinal canal decompression in burst fractures treated with pedicle screw instrumentation. Spine (Phila Pa 1976). 1996;21(1):113-23.

16. Alanay A, Acaroglu E, Yazici M, Oznur A, Surat A. Short-segment pedicle instrumentation of thoracolumbar burst fractures: does transpedicular intracorporeal grafting prevent early failure? Spine (Phila Pa 1976). 2001;26(2):213-7

17. Andress HJ, Braun $H$, Helmberger T, Schürmann M, Hertlein $H$, Hartl WH. Long-term results after posterior fixation of thoracolumbar burst fractures. Injury. 2002;33(4):357-65.

18. Knop C, Fabian HF, Bastian L, Blauth M. Late results of thoracolumbar fractures after posterior instrumentation and transpedicular bone grafting. Spine (Phila Pa 1976). 2001;26(1):88-99.

19. Speth MJ, Oner FC, Kadic MA, de Klerk LW, Verbout AJ. Recurrent kyphosis after posterio stabilization of thoracolumbar fractures. Acta Orthop Scand. 1995:66(5):406-10.

20. Ouellet JA, Richards C, Sardar ZM, Giannitsios D, Noiseux N, Strydom WS, et al. Finite Element Analysis and Biomechanical Comparison of Short Posterior Spinal Instrumen- tation with Divergent Bridge Construct versus Parallel Tension Band Construct for Thoracolumbar Spine Fractures. Global Spine J. 2013;3(2):85-94.

21. Magerl F, Aebi M, Gertzbein SD, Harms J, Nazarian S. A comprehensive classification of thoracic and lumbar injuries. Eur Spine J. 1994:3(4):184-201.

22. Whang PG, Vaccaro AR. Thoracolumbar fracture: posterior instrumentation using distraction and ligamentotaxis reduction. J Am Acad Ortop Surg. 2007:15(11):695-701.

23. De Peretti F, Howorka I, Cambas PM, Nasr JM, Argenson C. Short device fixation and early mobilization for burst fractures of the thoracolumbar junction. Eur Spine J. 1996:5(2):112-20.

24. McLain RF, Sparling E, Benson DR. Early failure of short-segment pedicle instrumentation of thoracolumbar fractures. A preliminary report. J Bone Joint Surg Am. 1993:75(2):162-7.

25. Mumford J, Weinstein JN, Spratt KF, Goel VK. Thoracolumbar burst fractures. The clinical efficacy and outcome of nonoperative management. Spine (Phila Pa 1976). 1993;18(8):955-70.

26. Hitchon PW, Abode-lyamah K, Dahdaleh NS, Shaffrey C, Noeller J, He W, et al Nonoperative management in neuro- logically intact thoracolumbar burst fractures: clinical and radiographic outcomes. Spine (Phila Pa 1976). 2016;41(6):483-9.

27. Denis F, Armstrong GW, Searls K, Matta L. Acute thoracolumbar burst fractures in the absence of neurologic deficit. A comparison between operative and nonoperative treatment. Clin Orthop Relat Res. 1984;(189):142-9.

28. Roy-Camille R, Saillant G, Mazel C. Plating of thoracic, thoracolumbar, and lumbar injuries with pedicle screw plates. Orthop Clin North Am. 1986:17(1):147-59.

29. Wood KB, Li W, Lebl DR, Ploumis A. Management of thoracolumbar spine fractures. Spine J. 2014;14(1):145-64

30. Xu BS, Tang TS, Yang HL. Long-term results of thoracolumbar and lumbar burst fractures after short-segment pedicle instrumentation, with special reference to implant failure and correction loss. Orthop Surg. 2009;1(2):85-93.

31. Pellise F, Barastegui D, Hernandez-Fernandez A, Barrera-Ochoa S, Bago J, Issa-Benitez $D$, et al. Viability and long-term survival of short-segment posterior fixation in thoracolumbar burst fractures. Spine J. 2015;15(8):1796-803.

32. Vanderschot $P$, Broos $P$. Tricortical autologeus bone graft vs allografts in the treatment of fractures of the thoracolumbar spine. J Bone Joint Surg Br. 2001;83-B(Suppl 2):149.

33. van Loon JL, Slot GH, Pavlov PW. Anterior instrumentation of the spine in thoracic and thoracolumbar fractures: the single rod versus the double rod Slot-Zielke device. Spine (Phila Pa 1976). 1996;21(6):734-40

34. Yu SW, Fang KF, Tseng IC, Chiu YL, Chen YJ, Chen WJ. Surgical outcomes of short-segment fixation for thoracolumbar fracture dislocation. Chang Gung Med J. 2002;25(4):253-9.

35. Verlaan JJ, Diekerhof $\mathrm{CH}$, Buskens E, van der Tweel I, Verbout AJ, Dhert WJ, et al. Surgical treatment of traumatic fractures of the thoracic and lumbar spine: a systematic review of the literature on techniques, complications, and outcome. Spine (Phila Pa 1976). 2004:29(7):803-14.

36. Cheng LM, Wang JJ, Zeng ZL, Zhu R, Yu Y, Li C, et al. Pedicle screw fixation for traumatic fractures of the thoracic and lumbar spine. Cochrane Database Syst Rev. 2013;31(5):CD009073

37. Alpantaki K, Bano A, Pasku D, Mavrogenis AF, Papagelopoulos PJ, Sapkas GS, et al. Thoracolumbar burst fractures: a systematic review of management. Orthopedics. 2010;33(6):422-9.

38. Tezeren G, Kuru I. Posterior fixation of thoracolumbar burst fracture: short-segment pedicle fixation versus long-segment instrumentation. J Spinal Disord Tech. 2005;18(6):485-8.

39. Wang ST, Ma HL, Liu CL, Yu WK, Chang MC, Chen TH. Is fusion necessary for surgically treated burst fractures of the thoracolumbar and lumbar spine?: a prospective, randomized study. Spine (Phila Pa 1976). 2006;31(23):2646-52.

40. Sanderson PL, Fraser RD, Hall DJ, Cain CM, Osti OL, Potter GR. Short segment fixation of thoracolumbar burst fractures without fusion. Eur Spine J. 1999;8(6):495-500 